\title{
Essential and Nonessential Element Translocation in Corn Cultivated Under Sewage Sludge Application and Associated Health Risk
}

\author{
Denise Grotto • Bruno L. Batista • Juliana M. O. Souza • Maria F. H. Carneiro • \\ Diego dos Santos • Wanderley J. Melo • Fernando Barbosa Jr
}

Received: 22 April 2015 / Accepted: 1 July 2015 /Published online: 15 July 2015

(C) Springer International Publishing Switzerland 2015

\begin{abstract}
Sewage sludge has been used as a fertilizer in agriculture, but human exposure to toxins due to crop exposure has been reported. This study evaluated the uptake of essential and nonessential elements from soil (exposed to sewage sludge) to roots, shoots, and grains of corn, aiming to estimate the daily intake corn consumption to assess the associated health risk. Corn plants were grown in soil amended with $0,5,10$, and 20 tons of sewage sludge per hectare $(\mathrm{t} / \mathrm{ha})$. Soil, root, shoot, and grain samples were analyzed by inductively coupled plasma mass spectrometry. In soil, sludge application at 10 and $20 \mathrm{t} / \mathrm{ha}$ enhanced the $\mathrm{Zn}, \mathrm{Cu}, \mathrm{Mo}, \mathrm{Cd}$, $\mathrm{Pb}, \mathrm{Hg}$, and $\mathrm{Ni}$ concentration compared to control soil. Normally, corn plants exhibited essential and nonessential element concentrations significantly higher in roots
\end{abstract}

D. Grotto $(\bowtie)$

Universidade de Sorocaba, CEP 18023-000 Sorocaba, SP,

Brazil

e-mail: denise.grotto@prof.uniso.br

B. L. Batista

Centro de Ciências Naturais e Humanas, Universidade

Federal do ABC, CEP 09090-400 Santo André, SP, Brazil

J. M. O. Souza • M. F. H. Carneiro • D. dos Santos •

F. Barbosa Jr

Faculdade de Ciências Farmacêuticas de Ribeirão Preto, Universidade de São Paulo, CEP 14040-903 Ribeirão Preto, SP, Brazil

W. J. Melo

Departamento de Tecnologia, Faculdade de Ciências Agrárias e Veterinárias, UNESP, Universidade Estadual Paulista, CEP 14884-900 Jaboticabal, SP, Brazil than in grains and shoots. Selenium was equally distributed in roots, shoots, and grains but Mo was preferentially stored in grains. Cadmium, $\mathrm{As}$, and $\mathrm{Pb}$ were more efficiently trapped in roots than other elements. Considering the estimated daily intake, for Brazilians, the concentrations were below the toxicological or the dietary reference values. In conclusion, chemical elements were efficiently trapped in roots and therefore applying $5 \mathrm{t} /$ ha proportion of sewage sludge might be a sustainable and cost-effective strategy, with a very lower risk of toxicity due to consumption of grains. In contrast, sewage sludge at $20 \mathrm{t} / \mathrm{ha}$ enhanced element levels in plant parts and in places with higher corn consumption, estimated daily intakes are expected to rise.

Keywords Sewage sludge $\cdot$ Corn $\cdot$ Health risk $\cdot$ Toxic elements · Essential elements $\cdot$ Transfer factor

\section{Introduction}

Finite resources of commercial fertilizer components and the large amounts of sewage sludge (SS) produced worldwide have made cropland application of this residue an attractive disposal alternative (Vieira et al. 2014; Water UK 2010). According to a report elaborated by the European Commission in agreement with other institutions for the environmental, economic, and social impacts of the use of SS on land, $37 \%$ of SS (about 3.6 million of tons) have been used in agriculture in the European Union (European Commission 2010). 
Sewage sludge is rich in organic matter and nutrients, such as phosphorus $(\mathrm{P})$, nitrogen $(\mathrm{N})$, and several other micronutrients crucial to plant growth and development (Selma et al. 2010; Nogueirol et al. 2013).

Regardless of the economic benefits and sustainability of using SS as a biofertilizer, potential impacts on environment and health can occur. Toxic metals, organic compounds, as well as pathogens are the main causative agents (Muchuweti et al. 2006; Clarke and Smith 2011; Frąc et al. 2014; Meng et al. 2014; Nkoa 2014; Zoffoli et al. 2013; Pathak et al. 2013; Chen et al. 2014). For instance, crustaceans exhibited an increasing body length, a shift of the sex ratio in favor of females, and increased fraction of brooding females and fecundity indices after increasing estrogen-wastewater sewage concentrations (Schneider et al. 2015). Moreover, Grotto et al. (2013) found altered redox state parameters in rats chronically fed with a diet containing corn produced in soil treated with urban sewage sludge up to 10 tons/hectare.

Chemical element uptake by plants depends on several factors such as mode of cultivation, the quality of water used for irrigation, soil composition, and plant's capability to trap the pollutants in roots (Batista et al. 2014). A measure of plant's potential to relocate a specific compound from soil to roots, shoots, and grains is the transfer factor (TF) (Carbonell et al. 1998). The transfer factor is undoubtedly of significant importance since it is associated with the problem of soil pollution and plant toxicity due to sludge reuse and further consequences such as those related to food safety (Natzala et al. 2013). Nevertheless, experimental evidence on TF values is insufficient. Therefore, the aim of this study was to determine the concentration of essential and nonessential elements $(\mathrm{Zn}, \mathrm{Se}, \mathrm{Cu}, \mathrm{Mo}, \mathrm{As}, \mathrm{Cd}, \mathrm{Pb}$, $\mathrm{Hg}$, and $\mathrm{Ni}$ ) in soil, roots, shoots, and grains of corn (Zea mays L.) cultivated without and with crescent levels of SS. The TF of each of these chemical elements was calculated. In addition, associated health risk based on estimated daily intake of corn (grown and not grown with SS) was estimated.

\section{Materials and Methods}

\subsection{Experimental Design}

This study is part of a larger and long-term investigation in progress in the city of Jaboticabal, in the state São
Paulo, Brazil. In 2013, our team published a manuscript about the systemic oxidative stress effects in rats, after consuming a diet containing corn cultivated with SS (Grotto et al. 2013). This study is an extension of this previous work in order to assess the transport of compounds of interest into the plant tissues (TF) after sewage sludge application to soil and associated health risk based on estimated daily intake of corn.

Amounts of SS (expressed in dry basis) have been applied in the soil for 15 consecutive years provided from a sewage treatment plant from Companhia de Saneamento Básico do Estado de São Paulo (Sabesp) in the city of Franca (state of São Paulo, Brazil).

Corn seeds from the cultivar 2B710HX (Dow Agro Science $^{\circledR}$ ) were sown in 0.90-m spacing between rows and five to seven seeds per meter, in four adjacent bands containing different types of soil: (1) soil under mineral fertilization- $\mathrm{N}, \mathrm{P}_{2} \mathrm{O}_{5}, \mathrm{~K}_{2} \mathrm{O}$ (control soil, CS); (2) soil amended with 5 tons of SS per hectare (t/ha); (3) soil amended with $10 \mathrm{t} / \mathrm{ha}$; and (4) soil amended with $20 \mathrm{t} /$ ha. The selection of SS proportion was based on the percentage of $\mathrm{N}$ contained in it required by corn crop$5 \mathrm{t} / \mathrm{ha}$ means $50 \%$ of the required $\mathrm{N}$ by the corn, $10 \mathrm{t} / \mathrm{ha}$ means $100 \%$ of the required $\mathrm{N}$, and $20 \mathrm{t} / \mathrm{ha}$ means $200 \%$ of the required $\mathrm{N}$.

All experiments were conducted in typical eutroferric red latosol. Characteristics included the following: $\mathrm{pH}$, 5.7; organic matter, $34 \mathrm{~g} / \mathrm{dm}^{3}$; P concentration, $67 \mathrm{mg} /$ $\mathrm{dm}^{3} ; \mathrm{K}, \mathrm{Ca}$, and $\mathrm{Mg}$ concentrations, 4.9, 41.8, and $18.6 \mathrm{mmol} / \mathrm{dm}^{3}$, respectively; $\mathrm{H}^{+} \mathrm{Al}, 22 \mathrm{mmol} / \mathrm{dm}^{3}$; and cation exchange capacity, $87.3 \mathrm{mmol} / \mathrm{dm}^{3}$. Both mineral fertilizer and SS were added to soil before corn transplanting. The culture system was minimal cultivation: herbicide application to kill the plants that grew in the off season, harrowing to incorporate plant debris remaining, and harrowing depth of $10 \mathrm{~cm}$ to incorporate sewage sludge. Thus, the main difference between this experiment and the usual agricultural practices is receiving SS sludge doses for 14 consecutive years. Corn was chosen since it is the cereal with the highest production worldwide and Brazil is one of the largest producers. In addition, the cultivation is simple and corn plant can be harvested entirely both for human and animal consumption.

In order to evaluate the chemical element concentrations in soil, roots, shoots, and grains, ten samples of individual corn plants were randomly collected per group of soil treatment. Soil samples were collected at a depth of $20 \mathrm{~cm}$, during the flowering stage of corn 
plants (when the demand for water and nutrients from soil is increased), while plant tissues (roots, shoots, and grains) were collected at the harvesting stage. Accordingly, the corn was grown for about 110 days.

Soil samples were air dried at room temperature $(30 \pm$ $\left.3{ }^{\circ} \mathrm{C}\right)$. Roots, shoots, and grains were washed in ultrapure water, dried slightly on absorbent paper, weighed, frozen to $-80{ }^{\circ} \mathrm{C}$, and freeze-dried. After, samples were weighed again and percent of water lost was calculated. All samples were then milled and sieved (406 $\mu \mathrm{m}$ pore size).

\subsection{Assessment of Chemical Elements}

Chemical element levels ( $\mathrm{Zn}, \mathrm{Se}, \mathrm{Cu}, \mathrm{Mo}, \mathrm{As}, \mathrm{Cd}, \mathrm{Pb}$, $\mathrm{Hg}$, and $\mathrm{Ni}$ ) in the SS were analyzed using atomic absorption spectrometry, according to the US Environmental Protection Agency methodology (USEPA 1986). Zn, Se, Cu, Mo, As, Cd, Pb, Hg, and Ni concentrations were 705, 0.03, 204, 2.12, 0.12, 1.72, $39.1,0.002$, and $35.4 \mathrm{mg} / \mathrm{kg}$ dry weight, as previously published in Grotto et al. (2013). All chemical element concentrations were below the Brazilian upper acceptable limit (CONAMA Resolution number 375, 2006).

For the determination of $\mathrm{Zn}, \mathrm{Se}, \mathrm{Cu}, \mathrm{Mo}, \mathrm{As}, \mathrm{Cd}, \mathrm{Pb}$, $\mathrm{Hg}$, and Ni concentrations in soil, root, shoot, and grain samples, an inductively coupled plasma mass spectrometer equipped with a reaction cell (DRC-ICP-MS ELAN DRCII, PerkinElmer, SCIEX, Norwalk, CT, USA) operating with high-purity argon (99.999\%, Praxair, Brazil) was used. Soil, root, shoot, and grain samples were digested with nitric acid $\left(\mathrm{HNO}_{3}\right)$ and hydrogen peroxide $\left(\mathrm{H}_{2} \mathrm{O}_{2}\right)$ in an open system according to the method developed by Batista et al. (2014). Approximately $100 \mathrm{mg}$ of each sample was weighted in a $50-\mathrm{mL}$ plastic tube, and $2 \mathrm{~mL}$ of $\mathrm{HNO}_{3}$ was added. Samples remained $24 \mathrm{~h}$ at room temperature in a fume cupboard. After, $4 \mathrm{~mL}$ of $\mathrm{H}_{2} \mathrm{O}_{2}$ was added and the samples were heated at $60^{\circ} \mathrm{C}$ for $4 \mathrm{~h}$. Then, the volume was made up to $50 \mathrm{~mL}$ with ultrapure water and internal standard rhodium $(\mathrm{Rh})$ at $10 \mu \mathrm{g} / \mathrm{L}$ was used.

In order to check the accuracy of the data-certified reference materials, clay soil (Quality Control Material LGCQC3004), marine sediment reference material (HISS-1), rice flour (Standard Reference Material 1568A), and Virginia tobacco leaves (CTA-VTL-2) were prepared and analyzed as experimental samples. Values found were in agreement with the certified values (Table 1).

\subsection{Chemical Element Translocation in the Plant}

Transfer factors were calculated according to Raab et al. (2005). The TFs were calculated by dividing the concentration of the element obtained in the plant part (roots, shoots, or grains) by the level of it in soil. For instance, a higher value of TF soil/roots means that a higher amount of that element was translocated to the roots from soil. The following TFs were calculated: soil/roots, soil/shoots, and soil/grains.

\subsection{Estimation of Daily Intake}

The estimated daily intake was calculated based on estimates of the amount of corn consumed in Brazil (ABIMILHO 2012) - about $18 \mathrm{~kg} /$ capita/year — and on the concentration of elements in corn grains. The average percent of water in mass lost in freeze-drying was $73.9 \pm 2.4 \%$. The estimated daily intake was calculated using the following formula:

$\mathrm{EDI}=\mathrm{Ec} \times M$

in which EDI is the estimated daily intake of an element (mg/day/person or $\mu \mathrm{g} /$ day/person); Ec is the element concentration in raw corn grains; and $M$ is the mass of corn consumed daily in Brazil.

Regarding nonessential elements, concentrations obtained were compared to the toxicological reference value, such as the benchmark dose lower confidence limit of $1 \%$ extra risk $\left(\mathrm{BMDL}_{0.1}\right)$ for As (EFSA 2009), the provisional tolerable monthly intake for $\mathrm{Cd}(\mathrm{FAO} /$ WHO 2010), the benchmark dose lower confidence limit based on cardiovascular effects for $\mathrm{Pb}$ (EFSA 2010), and the tolerable daily intake for $\mathrm{Ni}$ (Environment Agency 2009). For essential elements, results were compared to the dietary reference intakes (DRI) from the Food and Nutrition Board of the Institute of Medicine, 1997-2001 (IOM 2002) since Brazil does not have its own dietary reference intake.

\subsection{Statistical Analyses}

Essential and nonessential element levels were reported as mean \pm standard deviation (SD), and the results were found to be nonparametric. Thus, comparisons among the concentrations of the elements in soil, roots, shoots, and grains were made using one-way nonparametric ANOVA, followed by Tukey's multiple range test. 
Table 1 Analytical performance for the determination of chemical elements in certified reference material concentrations found are represented as mean $\pm \mathrm{SD}$

\begin{tabular}{|c|c|c|c|c|c|c|c|c|}
\hline & \multicolumn{2}{|l|}{ Soil $^{\mathrm{a}}$} & \multicolumn{2}{|l|}{ Sediment $^{\mathrm{b}}$} & \multicolumn{2}{|l|}{ Rice $^{c}$} & \multicolumn{2}{|c|}{ Tobacco leaves $^{\mathrm{d}}$} \\
\hline & $\begin{array}{l}\text { Target } \\
\text { concentration }\end{array}$ & $\begin{array}{l}\text { Found } \\
\text { concentration }\end{array}$ & $\begin{array}{l}\text { Target } \\
\text { concentration }\end{array}$ & $\begin{array}{l}\text { Found } \\
\text { concentration }\end{array}$ & $\begin{array}{l}\text { Target } \\
\text { concentration }\end{array}$ & $\begin{array}{l}\text { Found } \\
\text { concentration }\end{array}$ & $\begin{array}{l}\text { Target } \\
\text { concentration }\end{array}$ & $\begin{array}{l}\text { Found } \\
\text { concentration }\end{array}$ \\
\hline $\mathrm{Zn}(\mathrm{mg} / \mathrm{kg})$ & 82 & $74 \pm 9$ & $4.94 \pm 0.79$ & $3.28 \pm 0.92$ & $19.4 \pm 0.5$ & $19.8 \pm 0.3$ & $43.3 \pm 2.1$ & $42.1 \pm 1.2$ \\
\hline $\mathrm{Se}(\mu \mathrm{g} / \mathrm{kg})$ & $<3000$ & $1100 \pm 400$ & $50 \pm 7$ & $39 \pm 12$ & $380 \pm 40$ & $480 \pm 70$ & 188 & $138 \pm 27$ \\
\hline $\mathrm{Cu}(\mathrm{mg} / \mathrm{kg})$ & 300 & $358 \pm 67$ & $2.29 \pm 0.37$ & $2.75 \pm 0.21$ & $2.4 \pm 0.3$ & $3.1 \pm 0.5$ & $18.2 \pm 0.9$ & $16.1 \pm 1.8$ \\
\hline Mo (mg/kg) & 2 & $1.5 \pm 0.4$ & 0.13 & $0.11 \pm 0.03$ & $1.46 \pm 0.08$ & $1.49 \pm 0.05$ & $2.01 \pm 0.15$ & $2.43 \pm 0.29$ \\
\hline As $(\mu \mathrm{g} / \mathrm{kg})$ & 83000 & $65000 \pm 15000$ & $801 \pm 99$ & $734 \pm 56$ & $290 \pm 30$ & $280 \pm 40$ & $969 \pm 72$ & $823 \pm 102$ \\
\hline $\mathrm{Cd}(\mu \mathrm{g} / \mathrm{kg})$ & $<1000$ & $400 \pm 100$ & $24 \pm 9$ & $22 \pm 3$ & $22 \pm 2$ & $25 \pm 3$ & $1520 \pm 170$ & $1310 \pm 90$ \\
\hline $\mathrm{Pb}(\mathrm{mg} / \mathrm{kg})$ & 50 & $45 \pm 7$ & $3.13 \pm 0.40$ & $2.52 \pm 0.39$ & $<0.010$ & $<\mathrm{LOD}$ & $22.1 \pm 1.2$ & $23.4 \pm 2.6$ \\
\hline $\begin{array}{l}\mathrm{Hg}^{\mathrm{e}}(\mathrm{mg} / \mathrm{kg} \\
\quad \text { and } \mu \mathrm{g} / \mathrm{kg})\end{array}$ & 670 & $656 \pm 29$ & 10 & $17 \pm 4$ & $5.8 \pm 0.5$ & $4 \pm 1$ & $48 \pm 9$ & $60 \pm 8$ \\
\hline $\mathrm{Ni}(\mathrm{mg} / \mathrm{kg})$ & 61 & $59 \pm 5$ & $2.16 \pm 0.29$ & $2.80 \pm 0.51$ & NA & $<\mathrm{LOD}$ & $1.98 \pm 0.21$ & $2.41 \pm 0.28$ \\
\hline
\end{tabular}

$N A$ not available; $L O D$ limit of detection

${ }^{\text {a }}$ Clay soil-Quality Control Material LGCQC3004

${ }^{\mathrm{b}}$ Marine sediment reference material-HISS-1

${ }^{\mathrm{c}}$ Rice flour-Standard Reference Material 1568A

${ }^{\mathrm{d}}$ Virginia tobacco leaves (CTA-VTL-2)

${ }^{\mathrm{e}} \mathrm{Hg}$ concentration in soil is expressed in milligrams per kilogram, and $\mathrm{Hg}$ concentration in sediment, rice, and tobacco leaves is expressed in micrograms per kilogram

$P$ values $<0.05$ were considered significant. Data were analyzed in Statistica software (Statistica ${ }^{\circledR}$, version 8.0).

\section{Results and Discussion}

The mean concentrations of essential and nonessential elements in samples of soil, roots, shoots, and grains cultivated in control soil and in soils spiked with different concentrations of SS are presented in Table 2. In soil samples, SS at both 10 and 20 t/ha augmented statistically $\mathrm{Zn}, \mathrm{Cu}, \mathrm{Mo}, \mathrm{Cd}, \mathrm{Pb}, \mathrm{Hg}$, and Ni concentrations in comparison to control soil. Moreover, SS at $20 \mathrm{t} / \mathrm{ha}$ produced a significant higher level of As. Considering specifically the 20-t/ha SS-amended soil, Zn was the most abundant element followed by $[\mathrm{Cu}]>[\mathrm{Ni}]>[\mathrm{Pb}]>[\mathrm{As}]>[\mathrm{Mo}]>[\mathrm{Se}]>[\mathrm{Cd}]>[\mathrm{Hg}]$. This pattern is somewhat similar to that published by Mantoviet al. (2005) regarding $\mathrm{Zn}, \mathrm{Cu}, \mathrm{Pb}$, and $\mathrm{Cd}$ levels after biosolid disposal in soil for 12 years. Moreover, other similarities considering magnitude of concentration in soil were reported by Bose and Bhattacharyya (2008) in two different soils amended with industrial sludge including $[\mathrm{Zn}]>[\mathrm{Pb}]$ and $[\mathrm{Cd}]$ $<[\mathrm{Zn}],[\mathrm{Pb}]$, and $[\mathrm{Ni}]$. On the other hand, there are differences such as $[\mathrm{Pb}]>[\mathrm{Ni}]$ and $[\mathrm{Cd}]>[\mathrm{Cu}]$. These variations are expected and can occur by different environmental conditions, such as soil $\mathrm{pH}$ and organic carbon content variations (Bhogal et al. 1993) as well as the singular sludge origin.

In general, considering the element distribution in plant parts, both essential and nonessential element concentrations were significantly higher in roots than in shoots and grains. This is explained by the compartmentalization and translocation processes in the vascular system of plants (Kim et al. 2003). The exception was Mo that presented the highest concentration in grains, followed by roots and shoots (Table 2). Considering the influence of the soil treatment in roots, both SS at 10 and 20 t/ha significantly increased $\mathrm{Zn}, \mathrm{Cu}, \mathrm{Mo}, \mathrm{Cd}, \mathrm{Pb}, \mathrm{Hg}$, and $\mathrm{Ni}$ concentrations in comparison to control soil whereas SS at 20 t/ha also enhanced As and Se concentrations. The soil treatment seemed to not interfere with the bioaccumulation of the elements in shoots. For instance, only using SS at $20 \mathrm{t} / \mathrm{ha}$, a significant accumulation of $\mathrm{Cu}, \mathrm{Cd}$, and $\mathrm{Pb}$ in shoots was observed in 
Table 2 Mean levels \pm standard deviation of chemical elements in soil, root, shoot, and grain samples grown in control soil (CS) and in soils spiked with different concentrations of sewage sludge $(5,10$, and $20 \mathrm{t} / \mathrm{ha})$

(10)

Data are reported in micrograms per gram or nanograms per gram (dry weight)

$L O D$ limit of detection

${ }^{*} p<0.05$ (statistically different from the control group; one-way nonparametric ANOVA followed by Tukey's multiple range test)

\begin{tabular}{|c|c|c|c|c|}
\hline & $\mathrm{CS}$ & $5 \mathrm{t} / \mathrm{ha}$ & $10 \mathrm{t} / \mathrm{ha}$ & $20 \mathrm{t} / \mathrm{ha}$ \\
\hline \multicolumn{5}{|l|}{ Soil sample } \\
\hline $\mathrm{Zn}(\mu \mathrm{g} / \mathrm{g})$ & $63.8 \pm 3.6$ & $74.4 \pm 11.4$ & $102.3 \pm 17.3 *$ & $124.9 \pm 26.9 *$ \\
\hline $\mathrm{Se}(\mathrm{ng} / \mathrm{g})$ & $576 \pm 136$ & $473 \pm 156$ & $575 \pm 269$ & $634 \pm 152$ \\
\hline $\mathrm{Cu}(\mu \mathrm{g} / \mathrm{g})$ & $76.2 \pm 3.8$ & $78.0 \pm 8.7$ & $88.7 \pm 7.2^{*}$ & $98.9 \pm 7.4^{*}$ \\
\hline Mo (ng/g) & $940 \pm 69$ & $1025 \pm 109$ & $1174 \pm 102 *$ & $1270 \pm 191 *$ \\
\hline As $(\mu \mathrm{g} / \mathrm{g})$ & $1.86 \pm 0.16$ & $2.03 \pm 0.16$ & $2.10 \pm 0.12$ & $2.19 \pm 0.20^{*}$ \\
\hline $\mathrm{Cd}(\mathrm{ng} / \mathrm{g})$ & $394 \pm 66$ & $429 \pm 36$ & $550 \pm 114^{*}$ & $614 \pm 200^{*}$ \\
\hline $\mathrm{Pb}(\mu \mathrm{g} / \mathrm{g})$ & $10.3 \pm 1.6$ & $11.4 \pm 1.6$ & $13.4 \pm 1.8^{*}$ & $14.6 \pm 1.3 *$ \\
\hline Hg (ng/g) & $6.2 \pm 0.7$ & $11.5 \pm 3.0$ & $18.2 \pm 3.6^{*}$ & $44.6 \pm 7.5^{*}$ \\
\hline $\mathrm{Ni}(\mu \mathrm{g} / \mathrm{g})$ & $14.0 \pm 0.4$ & $15.4 \pm 1.2$ & $18.2 \pm 1.4^{*}$ & $19.6 \pm 3.0^{*}$ \\
\hline \multicolumn{5}{|c|}{ Root sample } \\
\hline $\mathrm{Zn}(\mu \mathrm{g} / \mathrm{g})$ & $28.3 \pm 5.9$ & $42.4 \pm 20.4$ & $70.9 \pm 23.0^{*}$ & $66.4 \pm 13.2 *$ \\
\hline $\mathrm{Se}(\mathrm{ng} / \mathrm{g})$ & $165 \pm 68$ & $154 \pm 21$ & $172 \pm 57$ & $250 \pm 67 *$ \\
\hline $\mathrm{Cu}(\mu \mathrm{g} / \mathrm{g})$ & $21.4 \pm 7.4$ & $28.6 \pm 12.9$ & $43.5 \pm 9.6^{*}$ & $58.1 \pm 20.2^{*}$ \\
\hline Mo (ng/g) & $129 \pm 49$ & $181 \pm 59$ & $205 \pm 41 *$ & $295 \pm 77 *$ \\
\hline As (ng/g) & $356 \pm 139$ & $390 \pm 137$ & $432 \pm 74$ & $619 \pm 127^{*}$ \\
\hline Cd (ng/g) & $62 \pm 22$ & $49 \pm 20$ & $249 \pm 52 *$ & $304 \pm 70 *$ \\
\hline $\mathrm{Pb}(\mathrm{ng} / \mathrm{g})$ & $726 \pm 207$ & $985 \pm 376$ & $1299 \pm 280 *$ & $1734 \pm 410^{*}$ \\
\hline Hg (ng/g) & $2.3 \pm 1.3$ & $5.0 \pm 2.5$ & $13.6 \pm 3.1 *$ & $14.6 \pm 4.8^{*}$ \\
\hline $\mathrm{Ni}(\mu \mathrm{g} / \mathrm{g})$ & $1.5 \pm 0.6$ & $2.6 \pm 1.3$ & $6.5 \pm 2.7 *$ & $5.8 \pm 1.5^{*}$ \\
\hline \multicolumn{5}{|c|}{ Shoot sample } \\
\hline $\mathrm{Zn}(\mu \mathrm{g} / \mathrm{g})$ & $3.3 \pm 0.84$ & $3.5 \pm 1.30$ & $3.4 \pm 0.97$ & $3.6 \pm 1.22$ \\
\hline $\mathrm{Se}(\mathrm{ng} / \mathrm{g})$ & $85.2 \pm 22.3$ & $95.6 \pm 31.8$ & $88.2 \pm 12.7$ & $90.1 \pm 24.9$ \\
\hline $\mathrm{Cu}(\mathrm{ng} / \mathrm{g})$ & $651 \pm 117$ & $667 \pm 80$ & $642 \pm 51$ & $762 \pm 44^{*}$ \\
\hline Mo (ng/g) & $5.2 \pm 1.5$ & $5.4 \pm 1.4$ & $4.9 \pm 1.1$ & $5.2 \pm 1.3$ \\
\hline As (ng/g) & $28.9 \pm 4.8$ & $28.9 \pm 1.3$ & $25.6 \pm 2.2$ & $28.3 \pm 2.9$ \\
\hline $\mathrm{Cd}(\mathrm{ng} / \mathrm{g})$ & $3.1 \pm 1.0$ & $3.0 \pm 0.9$ & $4.0 \pm 1.4$ & $4.9 \pm 1.3 *$ \\
\hline $\mathrm{Pb}$ (ng/g) & $26.3 \pm 5.9$ & $24.1 \pm 3.6$ & $24.2 \pm 6.1$ & $42.6 \pm 8.9^{*}$ \\
\hline Hg (ng/g) & $<\mathrm{LOD}$ & $<\mathrm{LOD}$ & $<\mathrm{LOD}$ & $<\mathrm{LOD}$ \\
\hline Ni (ng/g) & $<\mathrm{LOD}$ & $<$ LOD & $<\mathrm{LOD}$ & $<$ LOD \\
\hline \multicolumn{5}{|c|}{ Grain sample } \\
\hline $\mathrm{Zn}(\mu \mathrm{g} / \mathrm{g})$ & $18.1 \pm 0.2$ & $20.9 \pm 0.6^{*}$ & $21.9 \pm 0.9^{*}$ & $27.6 \pm 2.1 *$ \\
\hline $\mathrm{Se}(\mathrm{ng} / \mathrm{g})$ & $103 \pm 16$ & $122 \pm 23$ & $138 \pm 27^{*}$ & $154 \pm 31^{*}$ \\
\hline $\mathrm{Cu}(\mu \mathrm{g} / \mathrm{g})$ & $2.7 \pm 0.3$ & $2.4 \pm 0.1$ & $2.4 \pm 0.1$ & $2.7 \pm 0.2$ \\
\hline Mo (ng/g) & $255 \pm 5$ & $248 \pm 6$ & $280 \pm 20 *$ & $426 \pm 13^{*}$ \\
\hline As (ng/g) & $4.2 \pm 1.7$ & $4.4 \pm 0.6$ & $8.9 \pm 1.4^{*}$ & $10.5 \pm 0.7^{*}$ \\
\hline Cd (ng/g) & $0.52 \pm 0.02$ & $0.83 \pm 0.28$ & $1.01 \pm 0.49$ & $1.76 \pm 0.75 *$ \\
\hline $\mathrm{Pb}$ (ng/g) & $4.7 \pm 3.1$ & $2.8 \pm 1.8$ & $33.1 \pm 6.6^{*}$ & $195.6 \pm 14.3^{*}$ \\
\hline Hg (ng/g) & $<\mathrm{LOD}$ & $<\mathrm{LOD}$ & $<\mathrm{LOD}$ & $<\mathrm{LOD}$ \\
\hline $\mathrm{Ni}(\mathrm{ng} / \mathrm{g})$ & $201 \pm 5$ & $219 \pm 6$ & $218 \pm 6$ & $577 \pm 31 *$ \\
\hline
\end{tabular}

comparison to controls. In fact, shoots can be proposed as the plant tissue in which the smallest amounts of chemical elements are retained. Moreover, in grains, except for $\mathrm{Cu}$, treatment with either 10 or $20 \mathrm{t} / \mathrm{ha}$ caused significant higher amounts of all nonessential elements in corn grains, i.e., toxic metals such as $\mathrm{Cd}, \mathrm{Pb}$, and $\mathrm{Ni}$. 
This result corroborates the study of Bose and Bhattacharyya (2008) who report $\mathrm{Pb}$ concentration in wheat grains is much higher in the plants grown in sewage-amended soils. Further, there was no difference considering $\mathrm{Cu}$ and $\mathrm{Hg}$ levels in corn grains due to soil treatment. This may be related to mechanisms of root to trap metals such as the presence of low molecular weight proteins that act like metal chelators leading to lower metal levels in leaves, fruits, and seeds (Clemens 2006).

The different TFs of both essential and nonessential elements in corn plants are showed in Figs. 1
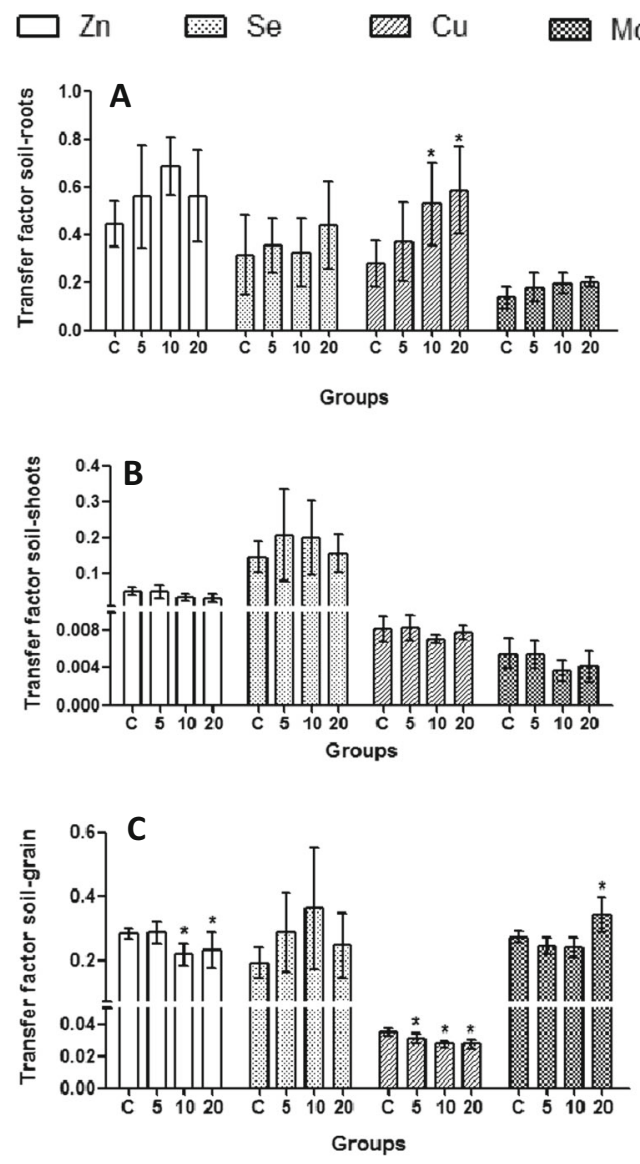

* Statistically different from control soil $(p<0.05)$.

Fig. 1 Transfer factor of essential elements $\mathrm{Zn}, \mathrm{Se}, \mathrm{Cu}$, and $\mathrm{Mo}$ among soil and plant parts exposed to sewage sludge in different concentrations $(C=$ control soil; $5=$ soil with sewage sludge at $5 \mathrm{t} /$ ha; $10=$ soil with sewage sludge at $10 \mathrm{t} / \mathrm{ha} ; 20=$ soil with sewage sludge at $20 \mathrm{t} / \mathrm{ha}$ ). Results presented as mean \pm standard deviation. a Transfer factor from soil to roots. b Transfer factor from soil to shoots. c Transfer factor from soil to grain. *Statistically different from control soil $(p<0.05)$ and 2 (respectively). TFs are able to indicate (i) how much the elements are immobilized in soil (availability); (ii) the site of primordial accumulation in the plant; and (iii) the nutritional/toxicological importance involving crops used for nutrition (Jarausch-Wehrheim et al. 1999).

Essential elements ( $\mathrm{Zn}, \mathrm{Se}, \mathrm{Cu}$, and $\mathrm{Mo}$ ) had different translocation intensities and target tissues in corn plants (Fig. 1). Zinc seems to be well trapped in roots in corn plants, with little being translocated to shoots and grains. This is explained by the increased $\mathrm{TF}$ soil/roots and shoots and grains with no


* Statistically different from control soil $(p<0.05)$.

Fig. 2 Transfer factor of nonessential elements $\mathrm{As}, \mathrm{Cd}$, and $\mathrm{Pb}$ among soil and plant parts exposed to sewage sludge in different concentrations $(C=$ control soil; $5=$ soil with sewage sludge at $5 \mathrm{t} /$ ha; $10=$ soil with sewage sludge at $10 \mathrm{t} / \mathrm{ha} ; 20=$ soil with sewage sludge at $20 \mathrm{t} / \mathrm{ha}$ ). Results presented as mean \pm standard deviation. a Transfer factor from soil to roots. b Transfer factor from soil to shoots. $\mathbf{c}$ Transfer factor from soil to grain. *Statistically different from control soil $(p<0.05)$ 
difference/decreased values of TF, respectively, when SS was used (Fig. 1a-c). Corroborating our findings, Jarausch-Wehrheim et al. (1999) found only $50 \mu \mathrm{g} / \mathrm{g}$ of $\mathrm{Zn}$ in corn grains cultivated in soil containing $\mathrm{Zn}$ at high levels $(400 \mu \mathrm{g} / \mathrm{g})$. Therefore, the TF soil/grains revealed that an increase in soil $\mathrm{Zn}$ concentration is not accompanied by an increase of it in the grains, since $\mathrm{Zn}$ is preferentially accumulated in the roots. At the same time, $\mathrm{Cu}$ had increasing concentrations in roots but only a small proportion being translocated to the aerial parts, even when SS $(5,10$, or $20 \mathrm{t} / \mathrm{ha})$ was added to soil (Fig. 1a-c). Several parameters influence the chemical element uptake such as soil $\mathrm{pH}$, cell transporters, and rhizosphere. For instance, Liu et al. (2000) observed that arbuscular mycorrhizal fungi have an important role on $\mathrm{Zn}, \mathrm{Cu}, \mathrm{Mn}$, and $\mathrm{Fe}$ uptake in $Z$. mays $\mathrm{L}$. since higher concentrations of $\mathrm{Cu}$ and $\mathrm{Zn}$ were found in shoots of plants containing these fungi.

Roots do not recognize low concentrations of chemical elements as a potential hazard. On the other hand, once there are elements in higher concentrations, such as in micrograms per gram, metal chelators are endogenously produced leading to higher rates of element trapping in roots (Clemens 2006). Selenium and Mo were found in magnitude of nanograms per gram in roots, shoots, and grains which probably contributed to intense uptake of Se and Mo. Considering Se, it was similarly distributed in roots, shoots, and grains, independently of soil treatment (Fig. 1a-c). On the other hand, Mo was preferentially stored in grains (Fig. 1c). In the group of plants that were exposed to SS at $20 \mathrm{t} / \mathrm{ha}$, Mo was significantly more accumulated in grains.

It was not possible to calculate $\mathrm{TFs}$ for $\mathrm{Hg}$ and $\mathrm{Ni}$ since their concentrations were lower than the limit of detection in some parts of corn plant. For this reason, $\mathrm{TFs}$ for $\mathrm{Hg}$ and $\mathrm{Ni}$ are not presented in Fig. 2. In roots, $\mathrm{Cd}$ was the nonessential element mostly accumulated followed by $\mathrm{As}$ and $\mathrm{Pb}$ (Fig. 2a). Higher amounts of both $\mathrm{Cd}$ and $\mathrm{Pb}$ in $\mathrm{SS}$ promoted higher values of $\mathrm{TF}$ soil/roots, i.e., higher accumulation of the elements in roots. Less than $0.5 \%$ of soil $\mathrm{As}$ and $\mathrm{Cd}$ were translocated to the grain $(\mathrm{TF}<0.005$, Fig. $2 \mathrm{c})$. The TF soil/grains for $\mathrm{Pb}$ was about 2 times higher than that regarding shoots (Fig. 2c). Although concentrations of both $\mathrm{As}$ and $\mathrm{Pb}$ in $\mathrm{SS}$ were in micrograms per gram, $\mathrm{Pb}$ showed more accumulation in grains than As ( $\mathrm{Pb} \mathrm{TF}>0.010$, Fig. 2c). Results corroborate Baig et al. who in 2010 defined the order of magnitude considering As accumulation in corn tissues as roots $>$ shoots $>$ grains (Baig et al. 2010). Moreover, the uptake of As occurs according to the chemical form. For example, Abbas and Meharg (2008) stated that inorganic As (arsenite and arsenate) has higher influx to the roots than dimethyl arsenic (organic form).

Roots and grains were the main sites of element accumulation. It is possible that roots were able to reduce the availability of some chemical element ions by producing specific proteins such as phytosiderophore and phytochelatins which are effective chelators of $\mathrm{Cd}$ and As. Cd-phytosiderophore complexes are apparently not taken up into root cells (Shenker et al. 2001), while As-phytochelatins trap As into root vacuoles (Batista et al. 2014). In both cases, the metal concentration in leaves, fruits, and seeds is usually lower (Wagner 1993). Our findings are in agreement since grains presented less $\mathrm{Cd}$ and $\mathrm{As}$ than did shoot and roots.

Mean consumption of corn is about $18 \mathrm{~kg} / \mathrm{capita} /$ year in Brazil (ABIMILHO 2012). The rate is much lower than in Mexico (98 kg/capita/year) (Ranum et al. 2014). In Africa, the consumption is much higher reaching $174 \mathrm{~kg} / \mathrm{capita} /$ year in Lesotho, according to the International Institute of Tropical Agriculture (IITA 2014). This food crop has been noticed as a staple food for many populations, mainly in Africa (Ranum et al. 2014).

Results on estimated daily intake of essential and nonessential elements from corn cultivated in the different soils are presented in Table 3. In general, the EDI of all elements was higher when corn grown in soils with SS at $20 \mathrm{t} /$ ha was used for calculation. The concentrations of nonessential elements were considerably below the toxicological reference values. In the case of SS at $20 \mathrm{t} / \mathrm{ha}$, Ni EDI was more than half $(7.4 \mu \mathrm{g} /$ day $)$ the value of toxicological reference $(12 \mu \mathrm{g} /$ day $)$ based on the developmental effects (animals) and skin hypersensitivity reactions (humans) after oral exposure (Environment Agency 2009; EPA 2000; ATSDR 2005). Although the EDI value for $\mathrm{Pb}$ (SS at $20 \mathrm{t} / \mathrm{ha}, 2.5 \mu \mathrm{g} /$ day) is significantly lower than the toxicological reference value (105 $\mu \mathrm{g} /$ day, based on cardiovascular effects by EFSA 2010), this EDI is 40 times higher than those obtained when corn was cultivated in CS or $5 \mathrm{t} / \mathrm{ha}$. Therefore, eating other foods that contain Ni can lead 
Table 3 Estimated daily intake of essential and nonessential elements according to consumption of corn grown in control soil (CS) and in soils spiked with increasing concentrations of sewage sludge $(5,10$, and $20 \mathrm{t} / \mathrm{ha}$ ) regarding Brazilian citizens

\begin{tabular}{|c|c|c|c|c|c|}
\hline \multirow[t]{2}{*}{ Analyte } & \multicolumn{4}{|c|}{ Estimated daily intake } & \\
\hline & $\mathrm{CS}$ & $5 \mathrm{t} / \mathrm{ha}$ & $10 \mathrm{t} / \mathrm{ha}$ & $20 \mathrm{t} / \mathrm{ha}$ & \\
\hline Nonessential element & & & & & Toxicological reference value \\
\hline As ( $\mu \mathrm{g} /$ day) & 0.05 & 0.06 & 0.11 & 0.13 & $21-560^{\mathrm{a}}$ \\
\hline Cd ( $\mu \mathrm{g} /$ day) & 0.01 & 0.01 & 0.01 & 0.02 & $58.3^{\mathrm{b}}$ \\
\hline $\mathrm{Pb}(\mu \mathrm{g} /$ day $)$ & 0.06 & 0.04 & 0.4 & 2.5 & $105^{\mathrm{c}}$ \\
\hline Ni ( $\mu$ g/day) & 2.6 & 2.8 & 2.8 & 7.4 & $12^{\mathrm{d}}$ \\
\hline Essential element & & & & & Dietary reference intake ${ }^{\mathrm{e}}$ \\
\hline $\mathrm{Zn}(\mu \mathrm{g} /$ day $)$ & 230 & 260 & 280 & 350 & $8000(\mathrm{~W}) / 11000(\mathrm{M})$ \\
\hline $\mathrm{Se}(\mu \mathrm{g} / \mathrm{day})$ & 1.3 & 1.6 & 1.8 & 2.0 & 55 \\
\hline $\mathrm{Cu}(\mu \mathrm{g} /$ day $)$ & 34 & 31 & 31 & 35 & 700 \\
\hline Mo ( $\mu \mathrm{g} /$ day) & 3.2 & 3.2 & 3.6 & 5.4 & 45 \\
\hline
\end{tabular}

$W$ woman, $M$ man

${ }^{a}$ Range of concentrations for the $95 \%$ lower confidence limit of the benchmark dose of $1 \%$ extra risk (BMDL $\left.{ }_{0.1}\right)\left(\mathrm{EFSA}_{2009)}\right.$

${ }^{\mathrm{b}}$ Provisional tolerable monthly intake/30 (FAO/WHO 2010)

${ }^{\mathrm{c}}$ Benchmark dose lower confidence limit (BMDL), based on cardiovascular effects (EFSA 2010)

${ }^{\mathrm{d}}$ Tolerable daily intake (TDI oral exposure): in micrograms per kilogram body weight per day based on the developmental effects seen in animals and the skin hypersensitivity reactions in humans (Environment Agency 2009)

${ }^{\mathrm{e}}$ Dietary reference intakes (DRI) for essential elements are the most recent set of dietary recommendations established by the Food and Nutrition Board of the Institute of Medicine (IOM 2002)

to toxicity. For As and Cd, even when SS at 20 t/ha was used, no significant risk of toxicity exists. Essential element levels in corn grains provided values below the dietary reference intake-considering all soil treatments. For Mo and Zn, soil supplementation with SS at $20 \mathrm{t} / \mathrm{ha}$ produced a slight rise in EDI, however still lower than the dietary reference value. For instance, consumption of corn grown with SS at 20 t/ha corresponded to $12 \%$ of Mo daily requirement. Overall results corroborate the study of Kidd et al. (2007) in which corn has been faced as the crop with the lowest metal concentrations after soil amendment with sewage.

\section{Conclusions}

This work adds new evidence on essential and nonessential element uptake from soil to different plant parts of corn in Brazil. The authors concluded that sewage sludge at 10 and $20 \mathrm{t} / \mathrm{ha}$ enhanced metal levels in plant parts, but not in a dose-dependent way. Transfer factor indicated that in general the elements were efficiently trapped in roots; however, both roots and grains were the main sites of element accumulation. Using a 5-t/ha proportion of SS to crop corn, a very lower risk of toxicity due to consumption of grains is predictable. $\mathrm{Ni}$ and $\mathrm{Pb}$ were efficiently transported to grains, and their EDIs due to consumption of corn cultivated with SS at $20 \mathrm{t} / \mathrm{ha}$ were considerably higher in comparison to those of corn produced in control soil. Moreover, several regions around the world have higher corn consumption, and in this way, EDIs are expected to rise, approaching the toxicological reference values.

Applying low quantities of SS per hectare might be a sustainable and cost-effective strategy considering corn crops. Despite the gains, the routine disposal of SS in agriculture demands more research to ensure food safety. Frequent surveillance is required since SS composition (as well as the rate of corn consumption) can vary worldwide.

Acknowledgments This work was supported by the São Paulo State Foundation for Scientific Research (FAPESP, No. 2011/00842-6). The excellent technical assistance of Vanessa C. de Oliveira Souza during the experiments is gratefully appreciated. 


\section{References}

Abbas, M. H. H., \& Meharg, A. A. (2008). Arsenate, arsenite and dimethyl arsenic acid (DMA) uptake and tolerance in corn (Zea mays L.). Plant and Soil, 304, 277-289.

ATSDR-Agency for Toxic Substances and Disease Registry. (2005). Toxicological profile for nickel.

Baig, J. A., Kazi, T. G., Shah, A. Q., et al. (2010). Evaluating the accumulation of arsenic in corn (Zea mays L.) plants from its growing media by cloud point extraction. Food and Chemical Toxicology, 48, 3051-3057.

Batista, B. L., Nigar, M., Mestrot, A., et al. (2014). Identification and quantification of phytochelatins in roots of rice to longterm exposure: evidence of individual role on arsenic accumulation and translocation. Journal of Experimental Botany, $65,1467-1479$.

Bhogal, N. S., et al. (1993). Micronutrient status in AquicUstifluvents and Udifluvents as related to certain soil properties. Journal of the Indian Society of Soil Science, 41, $75-78$.

Bose, S., \& Bhattacharyya, A. K. (2008). Heavy metal accumulation in wheat plant grown in soil amended with industrial sludge. Chemosphere, 70, 1264-1272.

Carbonell, A. A., et al. (1998). Arsenic in wetland vegetation: availability, phytotoxicity, uptake and effects on plant growth and nutrition. Science of the Total Environment, 217, 189-199.

Chen, H., Wang, Q., Jiang, Y., Wang, C., Yin, P., Liu, X., \& Lu, C. (2014). Monitoring and risk assessment of 74 pesticide residues in Pu-erh tea produced in Yunnan, China. Food Additives and Contaminants: Part B Surveillance, 8, 1-7.

Clarke, B. O., \& Smith, S. R. (2011). Review of 'emerging' organic contaminants in biosolids and assessment of international research priorities for the agricultural use of biosolids. Environment International, 37(1), 226-247.

Clemens, S. (2006). Toxic metal accumulation, responses to exposure and mechanisms of tolerance in plants. Biochimie, 88 , 1707-1719.

CONAMA - Conselho Nacional do Meio Ambiente. (2006). Environmental National Council. Brazil: Resolution number 375.

EC-European Commission. Environmental, economic and social impacts of the use of sewage sludge on land (2010). Consultation report on options and impacts. Milieu Ltd. WRc and RPA, Belgium. http://www.sede-environnement. com/sede-water/ressources/documents/1/15980,1-DraftImpact-Assessment-Sludge-D.pdf. Accessed 15 July 2014.

EFSA-European Food Safety Authority. EFSA Panel on Contaminants in the Food Chain (CONTAM). Scientific opinion on arsenic in food (2009). EFSA Journal, 7(10), 1351 (199 p.), doi:10.2903/j.efsa.2009.1351.

EFSA-European Food Safety Authority. EFSA Panel on Contaminants in the Food Chain (CONTAM). Scientific opinion on lead in food (2010). EFSA Journal, 8(4), 1570 (p.147).

Environmental Agency. (2009). Contaminants in soil: updated collation of toxicological data and intake values for humans. Nickel.

EPA (2000). United States Environmental Protection Agency. Nickel compounds. Hazard summary-created in April 1992; Revised in January 2000. Available from http:// www.epa.gov/ttnatw01/hlthef/nickel.html. Accessed 27 November 2014.

FAO/WHO. (2010). Joint FAO/WHO Expert Committee on Food Additives (JECFA). Geneva: 73th meeting Geneva.

Frąc, M., Oszust, K., Lipiec, J., Jezierska-Tys, S., \& Nwaichi, E. O. (2014). Soil microbial functional and fungal diversity as influenced by municipal sewage sludge accumulation. International Journal of Environmental Research and Public Health, 11(9), 8891-8908. doi:10.3390/ ijerph110908891.

Grotto, D., Carneiro, M. F. H., Sauer, E., Garcia, S. C., De Melo, W. J., \& Barbosa, F., Jr. (2013). Evaluation of biochemical and redox parameters in rats fed with corn grown in soil amended with urban sewage sludge. Ecotoxicology and Environmental Safety, 95, 188-194.

IITA - International Institute of Tropical Agriculture Available (2014). Available in http://www.iita.org/maize. Accessed 18 December 2014.

IOM - Institute of Medicine. (2002). Dietary reference intakes for vitamin $A$, vitamin $K$, arsenic, boron, chromium, copper, iodine, manganese, molybdenum, nickel, silicon, vanadium and zinc. Institute of Medicine, Washington (DC, USA): National Academy Press.

Jarausch-Wehrheim, B., Mocquot, B., \& Mench, M. (1999). Absorption and translocation of sludge-borne zinc in fieldgrown maize (Zea mays L.). European Journal of Agronomy, 11(1), 23-33.

Kidd, P. S., Domínguez-Rodríguez, M. J., \& Monterroso, C. (2007). Bioavailability and plant accumulation of heavy metals and phosphorus in agricultural soils amended by long-term application of sewage sludge. Chemosphere, 66, 1458-1467.

Kim, I. S., Kang, K. H., Johnson-Green, P., \& Lee, E. J. (2003). Investigation of heavy metal accumulation in Polygonum thunbergii for phytoextraction. Environmental Pollution, 126, 235-243.

Liu, A., Hamel, C., Hamilton, R. I., Ma, B. L., \& Smith, D. L. (2000). Acquisition of $\mathrm{Cu}, \mathrm{Zn}, \mathrm{Mn}$ and $\mathrm{Fe}$ by mycorrhizal corn (Zea mays L.) grown in soil at different $\mathrm{P}$ and micronutrient levels. Mycorrhiza, 9, 331-336.

Mantovi, P., Baldoni, G., \& Toderi, G. (2005). Reuse of liquid, dewatered, and composted sewage sludge on agricultural land: effects of long-term application on soil and crop. Water Research, 39, 289-296.

Meng, X. Z., et al. (2014). Flow of sewage sludge-borne phthalate esters (PAEs) from human release to human intake: implication for risk assessment of sludge applied to soil. Science of the Total Environment, 476-7, 242-249.

ABIMILHO-Associação Brasileira das Indústrias do Milho (2012) (in Portuguese). Resource Document. http://www. abimilho.com.br/noticias/29 Accessed 15 July 2014.

Muchuweti, M., Birkett, J. W., Chinyanga, E., et al. (2006). Heavy metal content of vegetables irrigated with mixture of wastewater and sewage sludge in Zimbabwe: implications for human health. Agriculture, Ecosystems \& Environment, $112,41-48$.

Nkoa, R. (2014). Agricultural benefits and environmental risks of soil fertilization with anaerobic digestates: a review. Agronomy for Sustainable Development, 34(2), 473-492.

Nogueirol, R. C., De Melo, W. J., Bertoncini, E. I., \& Alleoni, L. R. F. (2013). Concentrations of $\mathrm{Cu}, \mathrm{Fe}, \mathrm{Mn}$, and $\mathrm{Zn}$ in 
tropical soils amended with sewage sludge and composted sewage sludge. Environmental Monitoring and Assessment, 185, 2929-2938.

Ntzala, G., Koukoulakis, P. H., Papadopoulos, A. H., Leotsinidis, M., Sazakli, E., \& Kalavrouziotis, I. K. (2013). Interrelationships of pollution load index, transfer factor, and concentration factor under the effect of sludge. Environmental Monitoring and Assessment, 185(6), 52315242. doi:10.1007/s10661-012-2939-8.

Pathak, C., Chopra, A. K., \& Srivastava, S. (2013). Accumulation of heavy metals in Spinacia oleracea irrigated with paper mill effluent and sewage. Environmental Monitoring and Assessment, 185(9), 7343-7352. doi:10.1007/s10661-0133104-8.

Raab, A., Schat, H., Meharg, A. A., \& Feldmann, J. (2005). Uptake, translocation and transformation of arsenate and arsenite in sunflower (Helianthus annuus): formation of arsenic-phytochelatin complexes during exposure to high arsenic concentrations. New Phytologist, 168, 551-558.

Ranum, P., Peña-Rosas, J. P., \& Garcia-Casal, M. N. (2014). Global maize production, utilization, and consumption. Annals of the New York Academy of Sciences, 1312, 105-112.

Schneider, I., Oehlmann, J., \& Oetken, M. (2015). Impact of an estrogenic sewage treatment plant effluent on life-history traits of the freshwater amphipod Gammarus pulex. Journal of Environmental Science and Health, Part A: Toxic/ Hazardous Substances \& Environmental Engineering, 50(3), 272-281. doi:10.1080/10934529.2015.981114.
Selma, M. V., Martinez-Sanchez, A., Allende, A., Ros, M., Hernandez, M. T., \& Gil, M. I. (2010). Impact of organic soil amendments on phytochemicals and microbial quality of rocket leaves (Eruca sativa). Journal of Agricultural and Food Chemistry, 58, 8331-8337.

Shenker, M., Fan, T. W. M., \& Crowley, D. E. (2001). Phytosiderophores influence on cadmium mobilization and uptake by wheat and barley plants. Journal of Environmental Quality, 30, 2091-2098.

USEPA-United States Environmental Protection Agency. (1986). Test method for evaluating solid wastes. Washington: Report number SW-846.

Vieira, R. F., Moriconi, W., \& Pazianotto, R. A. (2014). Residual and cumulative effects of soil application of sewage sludge on corn productivity. Environmental Science and Pollution Research International, 21(10), 6472-6481. doi:10.1007/ s11356-014-2492-9.

Wagner, G. J. (1993). Accumulation of cadmium in crop plants and its consequences to human health. Advances in Agronomy, 51, 173-212.

UK Water. (2010). Recycling of biosolids to agricultural land. London, SW1H 9BT: Water UK.

Zoffoli, H. J., Do Amaral-Sobrinho, N. M., Zonta, E., Luisi, M. V., Marcon, G., \& Tolón-Becerra, A. (2013). Inputs of heavy metals due to agrochemical use in tobacco fields in Brazil's Southern Region. Environmental Monitoring and Assessment, 185(3), 2423-2437. doi:10.1007/s10661-0122721-y. 